\title{
Placebo virker i behandlingen av artrose
}

\author{
Placebo reduserer smerte og stivhet \\ og bedrer funksjonen hos pasienter \\ med artrose.
}

Det er utført mange placebokontrollerte behandlingsstudier av artrose, og nå foreligger for første gang en metaanalyse av placebos effekt i disse studiene (1).

Analysen omfattet 198 placebokontrollerte studier med 16364 pasienter, og resultatene er både interessante og tankevekkende. De viser at placebo signifikant reduserer smerte og stivhet og bedrer funksjonen. Disse effektene er signifikant bedre også i ubehandlede grupper. Effekten av placebo øker med behandlingseffekten av den utprøvende behandling, smertenivået ved studiestart, og studiepopulasjonens størrelse. Dessuten var effekten større hvis man benyttet injeksjoner fremfor tabletter eller annen form for administrasjon av placebo.

Resultatene ble kommentert på lederplass, og man konkluderer med at mange faktorer påvirker placeboeffekten, både forventede og uforventede (2). Placebos effekt er noe man alltid må regne med i kliniske studier, men også noe man kan optimalisere $\mathrm{i}$ behandlingen, slik som man ser i alternativ medisin. Lederskribenten konkluderer med

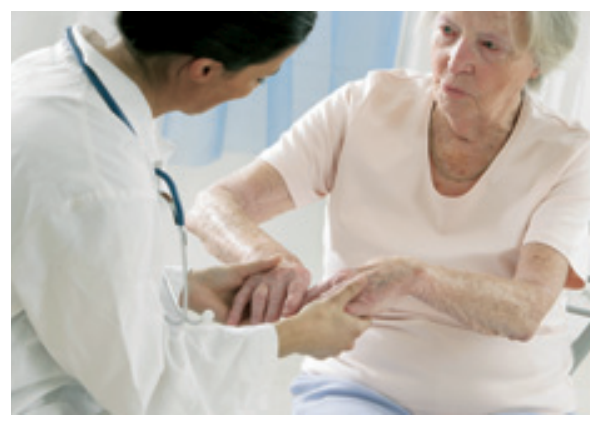

Illustrasjonsfoto BSIP/GV-Press/NordicPhotos

at det ikke er nødvendig å benytte placebo aktivt, men det er intet $\mathrm{i}$ veien for å optimalisere placeboeffekten $i$ behandlingen ved f.eks. å optimalisere lege-pasient-forholdet.

\section{Hans-Jacob Haga}

hjh@reumaklinikdanmark.dk

Reumaklinik Danmark

Esbjerg

\section{Litteratur}

Zhang W, Robertson J, Jones AC et al. The placebo effect and its determinants in osteoarthritis: metaanalysis of randomised controlled trials. Ann Rheum Dis 2008; 67: 1716-23.

2. Bijlsma JW, Welsing PM. The art of medicine in treating osteoarthritis: I will please. Ann Rheum Dis 2008; 67: 1653-5.

\section{Identiske celler reagerer forskjellig på kjemoterapi}

\section{Kreftceller som overlever kjemo-}

terapi, har annen proteinrespons enn genetisk identiske celler som dør av medikamentet.

Studier av en cellepopulasjon kan skjule fysiologiske særtrekk ved de enkelte celler. Lite er kjent om et medikaments effekt på enkeltcellenivå. Nå har forskere fra USA og Israel studert effekten av et kjemoterapimedikament, camptothecin, på humane kreftcellers proteinrespons (1).

Ved hjelp av retrovirus konstruerte de et bibliotek på 1200 cellekloner fra lungekarsinomceller. I hver av disse celleklonene knyttet man opp et gen for fluorescerende protein til et spesifikt cellulært gen. Nesten 1000 forskjellige, merkede proteiner i de individuelle cellene kunne studeres i rom og tid ved fluorescensmikroskopi. Resultatene tilkjennega at alle cellene viste en rask respons som var spesifikk for medikamentets virkningsmekanisme, men at undergrupper av proteiner hadde forskjellig dynamikk i individuelle celler. Disse forskjel- lene kunne relateres til cellenes evne til å overleve.

- Arbeidet er basert på bruk av veletablerte kloningsmetoder og mikroskopiske teknikker. Men med nye bioinformatiske analyseverktøy har man i motsetning til tidligere kunnet studere et enormt antall individuelle celler over tid, sier førsteamanuensis Kari Espolin Fladmark ved Molekylærbiologisk institutt, Universitetet i Bergen.

- Metodikken kan brukes til å gi en økt forståelse av hvorfor enkeltceller kan unnslippe ulike typer behandling og ikke minst identifisere de involverte proteinene. Disse «fluktproteinene» vil kunne være effektive mål i kombinasjonsbehandlinger, sier Fladmark.

\section{Trine B. Haugen \\ trine.b.haugen@hf.hio.no \\ Tidsskriftet}

\section{Litteratur}

Cohen AA, Geva-Zatorsky N, Eden E et al. Dynamic proteomics of individual cancer cells in response to a drug. Science 2008; 322: 1511-6.

\section{Migrene reduserer risikoen for brystkreft}

Frekvensen av migreneepisoder varierer med kvinners hormonelle syklus, og generelt er migrene assosiert med fallende østrogennivåer. En amerikansk forskningsgruppe har nå undersøkt sammenhengen mellom migrene og risikoen for utvikling av postmenopausal brystkreft (Cancer Epidemiol Biomarkers Prev 2008; 17: 3116-22).

Forskerne kombinerte data fra to populasjonsbaserte pasient-kontroll-studier, og benyttet data fra 1199 kvinner med duktal brystkreft, 739 med lobulær brystkreft og 1474 kontrollpersoner, alle i aldersgruppen 55-79 år. Man fant at kvinner med migrene hadde redusert risiko for utvikling av både duktal og lobulær brystkreft. Den reduserte risikoen var begrenset til utvikling av hormonreseptorpositiv brystkreftsykdom, og var uavhengig av migrenemedikasjon.

\section{Ikke sykehusinnleggelse ved mageblødninger?}

Enkle kliniske tester og laboratorietester kan identifisere pasienter med mageblødninger med lav risiko som trygt kan behandles utenfor sykehus. Det er konklusjonen på en studie i The Lancet (2008; doi: 10.1016/S0140-6736(08)61769-9).103-172 per 100000 voksne blir innlagt på sykehus med mageblødninger hvert år. Forfatterne evaluerte effektiviteten av Glasgow-Blatchford blødningsskår (GBS) som er basert på enkle kliniske tester og laboratorietester.

676 pasienter med mageblødninger innlagt ved fire engelske sykehus ble evaluert. $16 \%$ av pasientene skåret 0 (lav risiko). Ved to av sykehusene ble 123 (22\%) av pasientenes risiko klassifisert som lav, og 84 $(68 \%)$ av disse ble behandlet poliklinisk uten negative hendelser. Andelen pasienter med mageblødninger som ble innlagt ved sykehusene falt fra $96 \%$ til $71 \%$.

\section{Vaginal gel mot hiv?}

Carraguard, en bakteriedrepende vaginal gel, gir ingen beskyttelse mot hiv, konkluderer en studie i The Lancet 12008 ; 372 : 1977-87). $90 \%$ av nye hivinfeksjoner blant 15-24-åringer forekommer hos kvinner. Utvikling av legemidler som kan beskytte kvinner mot hiv er derfor viktig.

I denne randomiserte, placebokontrollerte studien fra Sør-Afrika ble 6202 seksuelt aktive kvinner randomisert til å få enten Carraguard eller placebogel som skulle brukes i tillegg til kondomer. Kvinnene ble fulgt opp hver tredje måned $i$ tre år. Hivinsidensen var 3,3 per 100 kvinneår i Carraguard-gruppen (134 infeksjoner) og 3,8 per 100 kvinneår i placebogruppen (151 infeksjoner). Forskerne estimerte at gelen i gjennomsnitt kun ble brukt ved $42,1 \%$ av samleiene. 